\title{
BIOKOMPOSIT DARI SERAT RAMI DAN SEKRESI KUTU LAK TERMODIFIKASI DENGAN LATEKS TERHIDRASI DAN TIDAK TERHIDRASI
}

\section{BIOCOMPOSITE OF RAMIE FIBER AND MODIFIED SECRETION OF LAC INSECT BY INCORPORATING HYDRATED AND UNHYDRATED LATEX}

\author{
Eli Rohaeti ${ }^{1, *}$, Mujiyono ${ }^{2}$, Rochmadi $^{3}$ \\ ' Jurusan Pendidikan Kimia FMIPA Universitas Negeri Yogyakarta, Karangmalang Yogyakarta 55281, Indonesia \\ ${ }^{2}$ Jurusan Teknik Mesin FT Universitas Negeri Yogyakarta, Karangmalang Yogyakarta 55281, Indonesia \\ ${ }^{3}$ Jurusan Teknik Kimia FT Universitas Gadjah Mada, Jl. Grafika No.2, Bulaksumur, Yogyakarta 55284, Indonesia \\ * Penulis korespondensi. Telp.: +62 274586168 Ext. 115; Fax.: +62 274548203 \\ E-mail: eli_rohaeti@uny.ac.id
}

Diterima: 2 Februari 2015 Direvisi: 24 April 2015 Disetujui: 1 Juni 2015

\begin{abstract}
Biocomposites are composite materials comprising one or more phases derived from a biological origin. Biocomposite with natural matrix developed more rapidly because they are more environmentally safer. The objective of research was to modify natural matrix from lac insect secretion with adding hydrated latex, to study effect of adding hydrated latex to the functional groups and the intrinsic viscosity of lac insect secretion, and to measure mechanical properties of biocomposite from modified lac insect secretion and ramie fiber. A sulfuric acid solution was used as catalyst in hydration of latex and then natural matrix of lac insect secretion was modified by adding hydrated latex. Biocomposite was prepared by mixing rami fiber and modified lac insect secretion. It was then pressed with hydraulic press at $150 \mathrm{kgf} / \mathrm{cm}^{2}$ and $150^{\circ} \mathrm{C}$ for 15 minutes. Biocomposites were characterized using tensile tester according to ASTDM D 638-90 Type IV. The adding of catalyst caused the decreasing of intrinsic viscosity of latex. The adding of hydrated latex to natural matrix caused the increasing of intrinsic viscosity and functional group of matrix. The using 30\% of catalyst and adding $10 \%$ of hydrated latex produced biocomposite with strength at break of $0.982 \mathrm{MPa}$, elongation at break of 1.189\%, and Young modulus of $0.929 \mathrm{MPa}$.
\end{abstract}

Keywords: biocomposite, hydration, latex, lac insect secretion, ramie fiber.

\begin{abstract}
ABSTRAK
Biokomposit merupakan material komposit yang tersusun dari satu atau lebih komponennya berasal dari bahan alam. Biokomposit dari matriks alam berkembang lebih pesat karena lebih aman bagi lingkungan. Tujuan penelitian ini adalah untuk memodifikasi matriks dari sekresi kutu lak dengan penambahan lateks hasil hidrasi, mempelajari pengaruh penambahan lateks hasil hidrasi terhadap gugus fungsi dan viskositas intrinsik matriks, dan untuk mengukur sifat mekanik biokomposit dari matriks hasil modifikasi dengan serat rami. Lateks dihidrasi dengan variasi katalis asam sulfat 10, 20, dan 30\% (m/m). Matriks alam dari sekresi kutu lak dimodifikasi dengan penambahan lateks hasil hidrasi sebanyak 5, 10, dan 15\% (m/m). Biokomposit dibuat melalui pencampuran sekresi kutu lak hasil modifikasi dengan serat rami dan dipress pada tekanan $150 \mathrm{kgf} / \mathrm{cm}^{2}$ dan suhu $150^{\circ} \mathrm{C}$ selama $15 \mathrm{menit}$. Biokomposit dikarakterisasi menggunakan tensile tester sesuai dengan ASTDM D 638-90 tipe IV. Penambahan katalis menurunkan viskositas intrinsik lateks terhidrasi. Penambahan lateks terhidrasi meningkatkan viskositas intrinsik dan gugus fungsi matriks. Biokomposit dari matriks alam sekresi kutu lak termodifikasi lateks terhidrasi dengan penggunaan katalis 30\% dan penambahan lateks terhidrasi sebesar 10\% mempunyai kuat tarik sebesar 0,982 MPa, elongasi saat putus sebesar 1,189\%, dan modulus Young sebesar 0,929 MPa.
\end{abstract}

Kata kunci: biokomposit, hidrasi, lateks, sekresi kutu lak, serat rami. 


\section{PENDAHULUAN}

Komposit merupakan bahan polimer yang sudah banyak digunakan oleh beberapa industri, antara lain industri otomotif untuk eksterior dan interior otomotif, industri furniture, industri elektronik, industri makanan sebagai bahan pembungkus makanan, dan lain-lain. Komposit merupakan gabungan dari matriks dan penguat yang digabung menjadi satu bahan dan secara mikroskopis bahan pembentuknya masih terlihat seperti aslinya serta memiliki hubungan kerja di antara komponen pembentuknya sehingga mampu menampilkan sifat-sifat yang diinginkan.

Sebagian besar komposit yang selama ini dimanfaatkan berasal dari bahan sintetik yang tidak dapat diperbaharui seperti serat gelas, serat karbon, dan serat grafit. Matriks yang digunakan adalah polimer jenis termoset seperti epoksi, poliester tersulfonasi, dan polipropilen (Sordi et al., 2011; Feng et al., 2011), akan tetapi bahan-bahan tersebut mahal dan tidak ramah lingkungan. Ahmed et al. (2013) mempreparasi komposit dari matriks poliester tidak jenuh dari hasil glikolisis limbah polietilen tereftalat (PET) dengan dietilen glikol dan penambahan kaolin sebagai pengisi yang dapat digunakan untuk insulasi. Salah satu alternatif untuk menghasilkan komposit dengan biaya lebih ekonomis dan ramah lingkungan adalah mencari bahan pengganti salah satu atau kedua komponen pembentuk komposit tersebut. Apabila bahan pengganti matriks dan atau serat komposit berasal dari alam disebut sebagai biokomposit.

Quirino et al. (2014) mengungkapkan bahwa penggunaan biokomposit pengganti plastik yang berasal dari petroleum di industri pelapis dan industri komposit memiliki potensi yang menjanjikan karena bahan alam lebih melimpah, lebih murah dan terbarukan serta memiliki sifat mekanik tinggi. Matriks yang digunakan dapat berasal dari minyak nabati, kulit kacang mete, polisakarida, polylactide acid (PLA), polyhydroxyalkanoates, protein, dan lignin. Agustin et al. (2014) mengungkapkan bahwa biokomposit dapat dipreparasi dari selulosa nanokristal dengan matriks pati. Nilai kuat tarik dan modulus dapat diperoleh pada harga maksimum ketika pati dicampur dengan selulosa pada perbandingan sebesar 100:5, namun sifat termal mengalami penurunan dengan adanya penambahan selulosa nanokristal.

Biokomposit merupakan suatu material yang dibentuk dari matriks dan diperkuat dengan serat, salah satu atau kedua penyusunnya berasal dari alam. Bahan alam yang dapat digunakan sebagai matriks alam adalah sekresi kutu lak (Mujiyono et al., 2010). Lak merupakan hasil sekresi kutu lak (Laccifer lacca Kerr) dari tanaman Kesambi (Schleichera oleosa), Widoro atau Kaliandra (Zizypos jujube), Acacia vilosa dan A. Arabica (Taskirawati et al., 2008). Sekresi kutu lak merupakan salah satu bahan alam yang dapat direkayasa dan dimodifikasi menjadi matriks alam penyusun biokomposit. Lak termasuk dalam kelompok resin yang diperoleh dari hasil sekresi insekta Laccifer lacca Kerr (kutu lak) yang hidup pada tanaman inangnya. Sekresi kutu lak memiliki kandungan utama asam aleurat yang mempunyai ikatan kuat. Sekresi kutu lak mempunyai sifat biodegradable dan tidak beracun sehingga layak digunakan sebagai matriks dalam biokomposit.

Berdasarkan penelitian Mujiyono et al. (2010) sekresi kutu lak ini dapat direkayasa menjadi matriks alam untuk biokomposit. Penyusun utama sekresi kutu lak yaitu asam aleurat (Mujiyono et al., 2010) yang merupakan asam karboksilat dengan panjang rantai karbon 16.

Serat alam yang dapat digunakan untuk pembuatan biokomposit antara lain serat ijuk, serat pisang, serat sabut kelapa (Oroh et al., 2013), serat rami (Mujiyono et al., 2010). Serat alami memiliki beberapa keuntungan dibandingkan dengan serat sintetis, seperti berat yang lebih ringan, merupakan bahan terbarukan, ramah lingkungan dan kekakuan yang relatif lebih tinggi (Lokana et al., 2010). Serat pada biokomposit digunakan sebagai bahan pengisi dan berfungsi untuk menahan sebagian besar gaya yang bekerja pada bahan komposit, oleh karena itu pemilihan bahan serat harus memperhatikan sifat serat, yaitu kuat, kaku dan getasnya (Adistya, 2013). Serat rami memiliki kekuatan yang relatif tinggi di antara kelompok serat tumbuhan (Rudianto, 2012) dan apabila dibandingkan dengan kapas, serat rami juga lebih kuat (Feng et al. 2011). Besar kekuatan mekanik dari komposit berpenguat serat bergantung pada orientasi serat penyusun. Serat yang disusun secara acak pada komposit akan memiliki kekuatan tarik yang sama pada semua bidang arah tarikan.

Berbagai penelitian telah dikembangkan untuk meningkatkan kualitas biokomposit. Mujiyono (2010) telah berhasil melakukan penelitian biokomposit menggunakan sekresi kutu lak sebagai matriks alam dan serat rami sebagai penguat (Purwati, 2010). Kekuatan tarik biokomposit yang dihasilkan pada penelitian Mujiyono 
et al. (2010) sebesar $87 \mathrm{MPa}$, selanjutnya Puspita (2013) melakukan penelitian untuk memperbaiki sifat mekanik biokomposit dengan menambahkan lateks ke dalam matriks alam sekresi kutu lak berpenguat serat rami. Biokomposit hasil penelitian Puspita (2013) memiliki kuat tarik lebih kecil yaitu sebesar 11,5190 MPa. Penurunan kekuatan tarik pada penelitian Puspita (2013) dapat disebabkan karena tidak terbentuk ikatan antara lateks dengan sekresi kutu lak, sehingga perlu dilakukan modifikasi untuk membentuk ikatan antara lateks terhidrasi dengan sekresi kutu lak agar sifat mekanik biokomposit meningkat.

Beberapa penelitian tentang biokomposit mendorong adanya penelitian lebih lanjut untuk memodifikasi bahan penyusun biokomposit yang digunakan. Pada penelitian ini matriks yang digunakan adalah matriks alam sekresi kutu lak dengan modifikasi yaitu penambahan lateks terhidrasi. Modifikasi penambahan lateks terhidrasi pada matriks alam sekresi kutu lak diharapkan dapat meningkatkan massa molekul matriks alam sekresi kutu lak sehingga dapat memperbaiki sifat mekanik biokomposit.

Tujuan dari penelitian ini adalah untuk membuat material biokomposit dengan menggunakan serat rami sebagai penguat dan matriks alam termodifikasi lateks terhidrasi sebagai pengikat. Secara khusus, penelitian ini bertujuan untuk mempelajari pengaruh variasi jumlah katalis pada hidrasi lateks terhadap gugus fungsi lateks, pengaruh penambahan lateks hasil hidrasi ke dalam matriks alam dari sekresi kutu lak terhadap gugus fungsi dan viskositas matriks, serta pengaruh penambahan lateks hasil hidrasi optimum pada matriks alam dari sekresi kutu lak terhadap sifat mekanik biokomposit dengan penguat serat rami.

\section{BAHAN DAN METODE Bahan Penelitian}

Bahan utama yang digunakan yaitu hasil sekresi kutu lak dan lateks. Sekresi kutu lak yang digunakan berasal dari pohon Kesambi. Lateks alam yang digunakan yaitu lateks dari getah pohon karet di Palembang, Sumatera Selatan. Lateks ini diambil langsung dari perkebunan karet tanpa penambahan asam dan tanpa proses vulkanisasi. Lateks yang dipilih adalah lateks yang berwarna putih bersih dan berbau segar. Bahan-bahan lain yang digunakan dalam penelitian ini meliputi akuades $\left(\mathrm{H}_{2} \mathrm{O}\right)$, asam sulfat $\left(\mathrm{H}_{2} \mathrm{SO}_{4}\right) 18 \mathrm{M}, \mathrm{PE}$
(Petroleum Eter), tiner, aluminium foil, dan kertas saring.

\section{Peralatan Penelitian}

Peralatan yang digunakan dalam penelitian ini meliputi mesin uji tarik (Tensile tester) Universal Machine dan mesin pencetak biokomposit di Jurusan Teknik Mesin Fakultas Teknik UNY, Fourier Transform Infra Red Spectroscopy (FTIR) merk Shimadzu type 8400 S, magnetic stirrer dilengkapi dengan pemanas merek Cimarec, neraca analitik, viskometer Ostwald, piknometer $25 \mathrm{~mL}$, gelas kimia, pengaduk, termometer, penangas air, spatula, dan corong.

\section{Metode Penelitian \\ Hidrasi lateks}

Gambar 1 menunjukkan proses hidrasi lateks. Lateks padat sebanyak 3 gram dipotong lebih dahulu menjadi bagian-bagian kecil untuk selanjutnya dilarutkan. Pemotongan lateks ini dilakukan untuk mempercepat proses pelarutan. Lateks dilarutkan pada suhu kamar menggunakan PE dengan perbandingan 1:15 (Lateks:PE). Selanjutnya hidrasi dilakukan pada suhu $50^{\circ} \mathrm{C}$ selama 1 jam dengan penambahan $\mathrm{H}_{2} \mathrm{SO}_{4}$ pekat sebagai katalis dan $\mathrm{H}_{2} \mathrm{O}$ sebagai hidrator. Hidrasi Lateks dilakukan dengan 3 variasi jumlah katalis, yaitu $10 \%$, $20 \%$ dan $30 \%$ dari lateks $(0,17 \mathrm{~mL}, 0,35 \mathrm{~mL}$ dan

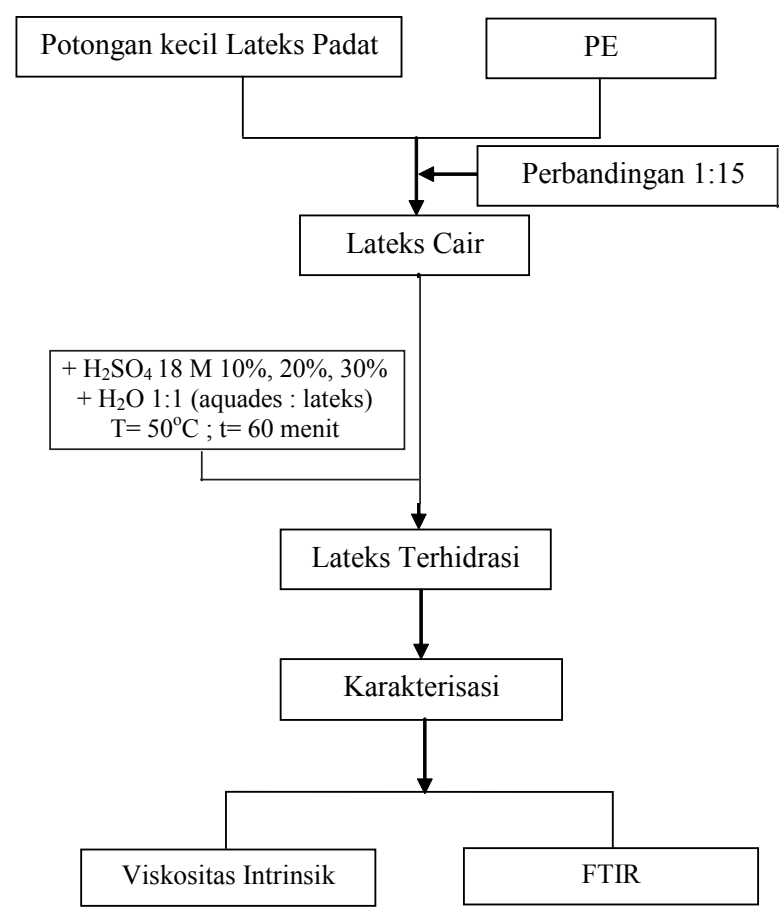

Gambar 1. Pembuatan lateks terhidrasi. 
$0,5 \mathrm{~mL}$ ). Adapun hidrator yang digunakan sebanding dengan jumlah lateks yang dihidrasi yaitu 3 gram. Lateks tanpa hidrasi dan lateks terhidrasi kemudian dianalisis gugus fungsi dan viskositasnya. Analisis gugus fungsi digunakan untuk mengetahui perubahan gugus fungsi yang terjadi, dimana ikatan rangkap dua pada lateks akan terputus setelah dihidrasi dan memiliki gugus $-\mathrm{OH}$ yang diharapkan akan berikatan dengan asam aleurat. Analisis viskositas digunakan untuk mengetahui pengaruh proses hidrasi terhadap perubahan viskositas lateks. Kedua analisis ini digunakan untuk menentukan lateks terhidrasi optimum yang akan digunakan untuk memodifikasi matriks.

\section{Matriks alam sekresi kutu lak}

Gambar 2 menunjukkan pembuatan matriks alam hasil modifikasi. Sekresi kutu lak yang digunakan berasal dari tanaman Kesambi yang merupakan tumbuhan inang dari budidaya kutu lak. Sekresi kutu lak ini masih berupa bongkahan kecil, sangat keras dan berwarna cokelat tua. Sebelum digunakan sebagai matriks alam, sekresi kutu lak terlebih dahulu dilarutkan menggunakan terpentin dengan perbandingan pelarut 1:2. Proses pelarutan sekresi kutu lak dengan terpentin dilakukan menggunakan magnetic stirrer sampai larut sempurna.

Kutu lak yang didapatkan kemudian digerus menjadi butiran yang lebih kecil yang selanjutnya dicairkan menggunakan tiner. Pelarutan Sekresi kutu lak (SKL) ini dilakukan pada suhu kamar dengan perbandingan pelarut 1:2 (SKL:tiner).

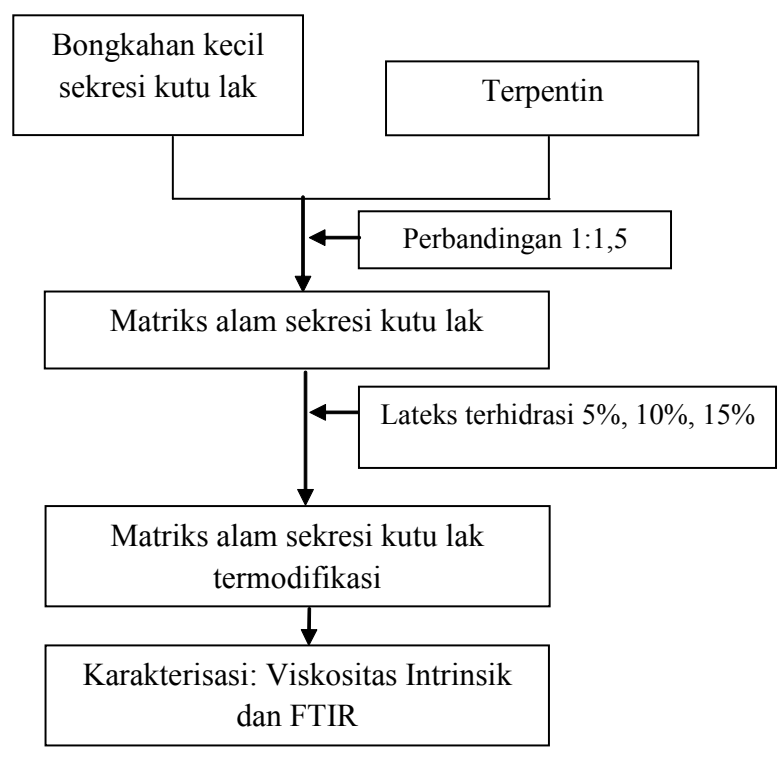

Gambar 2. Pembuatan matriks alam sekresi kutu lak termodifikasi.
SKL cair ini kemudian dianalisis menggunakan FTIR untuk mengetahui struktur asam aleurat yang terdapat dalam SKL.

\section{Modifikasi matriks}

Modifikasi matriks dilakukan dengan menambahkan lateks terhidrasi yang memiliki gugus -OH ke dalam SKL cair dengan kandungan utama asam aleurat yang merupakan asam karboksilat (-COOH). Blending ini dilakukan pada suhu $60^{\circ} \mathrm{C}$ selama 1 jam dengan variasi jumlah lateks terhidrasi sebesar 5\%, 10\%, dan $15 \%$. Pada matriks variasi $5 \%$ lateks terhidrasi, digunakan 9,5 gram sekresi kutu lak dan 0,5 gram lateks terhidrasi. Matriks variasi $10 \%$ lateks terhidrasi, digunakan 9 gram sekresi kutu lak dan 1 gram lateks terhidrasi. Matriks variasi $15 \%$ lateks terhidrasi digunakan 8,5 gram sekresi kutu lak dan 1,5 lateks terhidrasi. Proses ini menggunakan katalis untuk mempercepat reaksi esterifikasi antara gugus $-\mathrm{OH}$ pada lateks dan $-\mathrm{COOH}$ pada asam aleurat, katalis yang digunakan adalah $\mathrm{H}_{2} \mathrm{SO}_{4}$ pekat sebanyak $0,3 \mathrm{~mL}$. Matriks ini kemudian dianalisis menggunakan FTIR untuk mengetahui perubahan gugus fungsi yang terjadi, dimana gugus $\mathrm{OH}$ pada lateks diharapkan akan mengikat karbon positif pada asam aleurat dan membentuk ester melalui proses esterifikasi. Selain analisis menggunakan FTIR, juga dilakukan pengukuran viskositas. Kedua analisis ini digunakan untuk menentukan matriks termodifikasi optimum yang akan digunakan untuk membuat biokomposit. Sebagai kontrol, dilakukan juga blending antara asam aleurat dengan lateks tanpa hidrasi.

\section{Pengukuran viskositas intrinsik}

Lateks terhidrasi dengan variasi penambahan jumlah katalis $10 \%, 20 \%$ dan $30 \%$, diencerkan menggunakan PE pada konsentrasi $1 \%, 0,75 \%$, $0,5 \%, 0,25 \%$ dan $0,1 \%(\mathrm{~m} / \mathrm{m})$. Demikian pula matriks alam sekresi kutu lak dengan penambahan lateks terhidrasi, diencerkan pada konsentrasi $1 \%, 0,75 \%, 0,5 \%, 0,25 \%$ dan $0,1 \%(\mathrm{~m} / \mathrm{m})$ dengan menggunakan pelarut tiner.

Viskositas merupakan hasil kali antara waktu alir dengan massa jenis. Masing-masing konsentrasi tersebut ditimbang menggunakan piknometer dengan 3 kali pengulangan untuk mengukur massa jenis. Waktu alir diukur menggunakan viskometer Ostwald dengan cara menghitung waktu tempuh larutan dari garis batas atas mencapai garis batas bawah. Waktu alir masing-masing konsentrasi diukur dengan 5 kali pengulangan. Untuk matriks termodifikasi, sebelum dilakukan pengukuran ter- 
lebih dahulu dilakukan penyaringan menggunakan kertas saring untuk menghilangkan serpihanserpihan kayu yang tidak dapat larut.

Hasil analisis viskositas intrinsik lateks digunakan untuk mengetahui pengaruh esterifikasi terhadap viskositas matriks. Hasil analisis viskositas matriks termodifikasi dipadukan dengan hasil analisis gugus fungsi matriks termodifikasi untuk menentukan variasi matriks termodifikasi optimum yang akan digunakan sebagai bahan biokomposit.

\section{Analisis gugus fungsi dengan spektrofotometer FTIR}

Sampel lateks terhidrasi dan matriks termodifikasi yang akan dicari gugus fungsinya dicampur dengan $\mathrm{KBr}$ dan dibuat bentuk film. Pelet $\mathrm{KBr}$ dibuat dengan menggerus $\mathrm{KBr}$ sebanyak $200 \mathrm{mg}$, kemudian dilakukan revacum selama dua menit dan dipress selama 5 menit. Sampel dianalisis menggunakan spektrofotometer FTIR pada daerah $400-4000 \mathrm{~cm}^{-1}$. Spektrum yang dihasilkan berupa puncak-puncak gelombang $\% \mathrm{~T}$ terhadap panjang gelombang. Berdasarkan puncak-puncak yang muncul, dapat dianalisis gugus fungsi sampel.

\section{Pembuatan biokomposit}

Gambar 3 menunjukkan pembuatan biokomposit. Biokomposit dicetak menggunakan cetakan dengan ukuran $180 \mathrm{~mm}$ x $180 \mathrm{~mm}$ x $8 \mathrm{~mm}$.

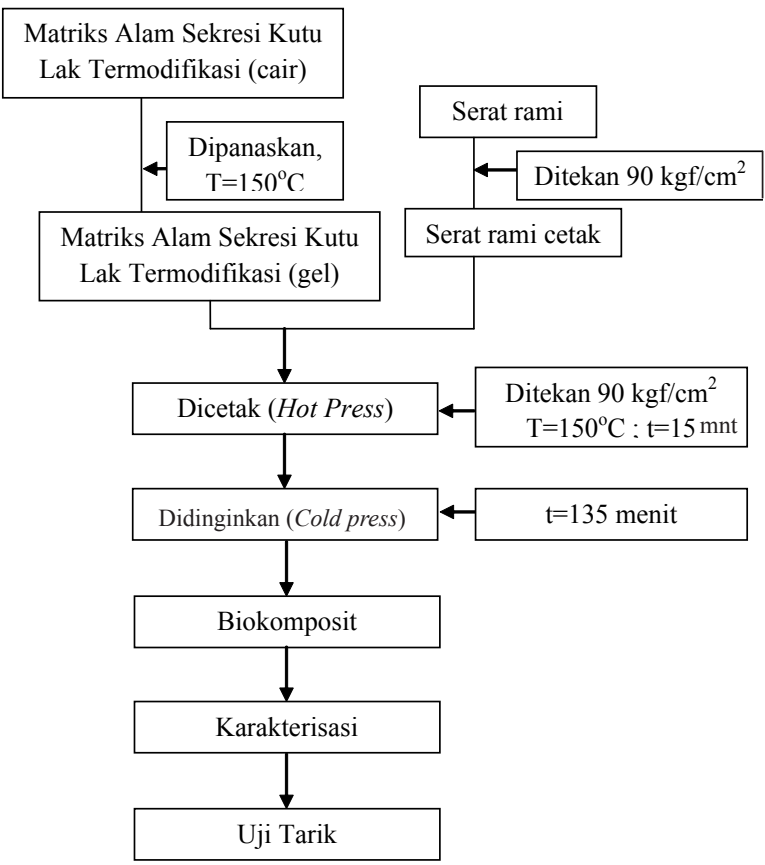

Gambar 3. Pembuatan biokomposit dari matriks alam sekresi kutu lak termodifikasi dengan penguat serat rami.
Perbandingan matriks dan serat yang digunakan yaitu $60 \%$ matriks : $40 \%$ serat. Sebanyak 259,718 gram matriks alam termodifikasi terlebih dahulu dihilangkan pelarutnya, kemudian dicampurkan dengan 165,88 gram serat rami yang telah disusun secara acak. Campuran matriks dengan serat tersebut dipress dengan tekanan $150 \mathrm{kgf} / \mathrm{cm}^{2}$ pada suhu $150^{\circ} \mathrm{C}$ selama 15 menit. Setelah itu, didinginkan pada suhu kamar selama 3 jam. Biokomposit yang dihasilkan berupa lembaran biokomposit.

\section{Analisis sifat mekanik}

Biokomposit dari matriks alam sekresi kutu lak termodifikasi lateks hidrasi dengan penguat serat rami selanjutnya dikarakterisasi menggunakan tensile tester untuk mengetahui sifat mekaniknya. Sifat mekanik yang dianalisis berupa kuat putus $(\sigma)$, perpanjangan saat putus $(\epsilon)$ dan Modulus Young. Sampel yang akan diuji dipotong menjadi bentuk dumbble. Kedua ujung spesimen uji dijepit kemudian pada salah ujungnya diaplikasikan suatu beban yang bertambah sedikit demi sedikit sampai sampel tersebut patah. Data yang dihasilkan berupa beban pada saat putus $(\mathrm{kN})$ dan perubahan panjang sampel pada saat putus. Data yang dihasilkan tersebut diolah menjadi kuat putus $(\sigma)$, perpanjangan saat putus $(\epsilon)$ dan modulus Young (E).

\section{HASIL DAN PEMBAHASAN Hidrasi Lateks}

Hidrasi menggunakan katalis $\mathrm{H}_{2} \mathrm{SO}_{4}$ pekat dengan variasi jumlah katalis yang digunakan, yaitu $10 \%, 20 \%$ dan $30 \%$ dari lateks, sedangkan $\mathrm{H}_{2} \mathrm{O}$ yang digunakan sesuai dengan jumlah lateks yang dihidrasi. Dalam hal ini katalis asam diperlukan karena molekul air yang netral tidak cukup asam untuk memberikan proton guna mengawali reaksi hidrasi. Sebelum lateks dihidrasi, lateks berwarna putih keruh. Setelah proses hidrasi, terjadi perubahan warna menjadi biru kehijauan.

Lateks yang digunakan dalam penelitian ini memiliki bentuk yang tidak simetris. Apabila suatu reagen dan atau suatu alkena keadaannya simetris, maka hanya ada satu kemungkinan produk hidrasi, tetapi apabila alkena maupun reagen (atau keduanya) yang digunakan tidak simetris, maka secara teori akan dihasilkan dua hasil yang merupakan isomer satu sama lain. Gambar 4 menunjukkan kemungkinan hasil hidrasi lateks pada penelitian ini.

Berdasarkan hukum Markovnikov yang mengatakan bahwa: "adisi elektrofilik suatu rea- 


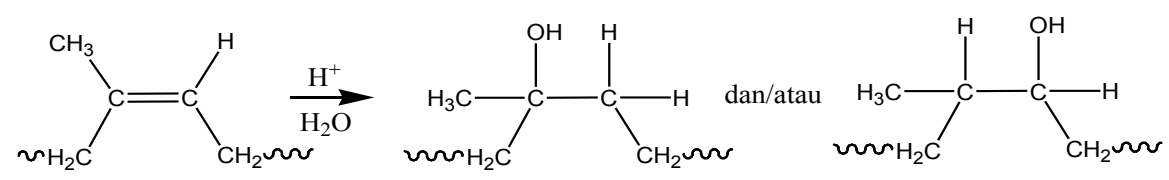

Gambar 4. Reaksi hidrasi lateks.

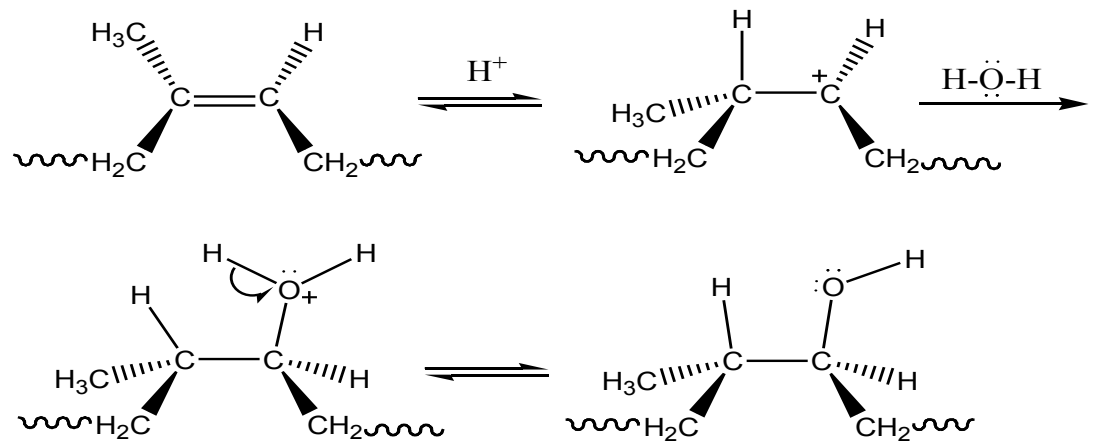

Gambar 5. Mekanisme reaksi hidrasi lateks.

gen tak simetrik pada ikatan rangkap tak simetrik berlangsung dengan cara melibatkan karbokation yang paling stabil", maka akan terbentuk satu hasil yang lebih dominan. Gambar 5 menggambarkan mekanisme reaksi pada hidrasi lateks yang akan menjawab hasil reaksi yang lebih dominan.

Dua tahapan yang terjadi pada reaksi ini, yang pertama adalah pembentukan karbokation oleh elektrofil $\mathrm{H}^{+}$yang terdapat pada asam sulfat. Tahap selanjutnya karbokation bergabung dengan nukleofil yang pada penelitian ini adalah molekul air. Di antara ketiga golongan karbokation (primer, sekunder, dan tersier), karbokation tersier yang paling stabil, disusul kemudian karbokation sekunder dan primer. Oleh karena itu kemungkinan produk yang dominan dihasilkan pada hidrasi lateks adalah produk kedua.

\section{Analisis FTIR}

Lateks yang telah dihidrasi kemudian dianalisis gugus fungsinya untuk mengetahui keberhasilan hidrasi. Analisis dilakukan dengan membandingkan spektrum FTIR lateks sebelum dan setelah hidrasi.

Berdasarkan hasil analisis terhadap spektrum FTIR dapat diketahui gugus fungsi yang terdapat pada lateks (Tabel 1). Serapan lemah muncul pada daerah $1666,67 \mathrm{~cm}^{-1}$ yang menunjukkan adanya ikatan $\mathrm{C}=\mathrm{C}$. Selain serapan $\mathrm{C}=\mathrm{C}$, terdapat juga serapan pada daerah $2958,55 \mathrm{~cm}^{-1}$ yang menunjukkan adanya ikatan $\mathrm{C}-\mathrm{H}$ stretching, dan daerah $1450,26 \mathrm{~cm}^{-1}$ yang menunjukkan adanya $\mathrm{C}-\mathrm{H}$ bending. Gugus fungsi metilen mempunyai vibrasi ikatan $\mathrm{C}-\mathrm{H}$ stretching pada daerah gelombang sekitar $2925 \mathrm{~cm}^{-1}$ (asymmetric) dan 2850

Tabel 1. Identifikasi puncak-puncak serapan FTIR lateks dan lateks terhidrasi

\begin{tabular}{lccccc}
\hline Ikatan atom & $\begin{array}{c}\text { Rentang } \\
\text { gelombang } \\
\left(\mathrm{cm}^{-1}\right)\end{array}$ & $\begin{array}{c}\text { Lateks tanpa } \\
\text { hidrasi }\end{array}$ & $\begin{array}{c}\text { Lateks terhidrasi } \\
10 \% \text { katalis } \\
\left(\mathrm{cm}^{-1}\right)\end{array}$ & $\begin{array}{c}\text { Lateks terhidra- } \\
\text { si } 20 \% \text { katalis } \\
\left(\mathrm{cm}^{-1}\right)\end{array}$ & $\begin{array}{c}\text { Lateks terhidrasi } \\
30 \% \text { katalis }\left(\mathrm{cm}^{-1}\right)\end{array}$ \\
\hline $\mathrm{C}=\mathrm{C}$ & $1620-1680$ & 1666,67 & 1643,86 & 1635,64 & 1651,07 \\
C-H & & & & & \\
Stretching & $2800-3100$ & 2958,55 & 2924,09 & 2924,09 & 2924,09 \\
Bending & $1300-1480$ & 1450,26 & 1452,62 & 1450,32 & 1458,18 \\
O-H & $3200-3600$ & - & 3442,21 & 3433,29 & 3417,85 \\
C-O & $1050-1150$ & - & 1091,83 & 1059,28 & 1059,28 \\
\hline
\end{tabular}


$\mathrm{cm}^{-1}$ (symmetric) serta vibrasi ikatan $\mathrm{C}-\mathrm{H}$ bending pada daerah $1465 \mathrm{~cm}^{-1}$. Berdasarkan data dan informasi tersebut, maka dapat diketahui bahwa lateks merupakan alkena yang memiliki gugus metilen, sesuai dengan keberadaannya dalam 1,4poliisoprena. Tabel 1 memberikan informasi serapan gugus fungsi yang terdapat pada lateks dan lateks terhidrasi dengan 10\%, 20\%, 30\% katalis.

Apabila dibandingkan dengan lateks tanpa hidrasi terlihat jelas perbedaan gugus fungsinya dimana lateks terhidrasi memiliki gugus $\mathrm{O}-\mathrm{H}$ pada daerah $3442,21 \mathrm{~cm}^{-1}, 3433,29 \mathrm{~cm}^{-1}$ dan 3417,85 $\mathrm{cm}^{-1}$ dengan kisaran rentangan $\mathrm{O}-\mathrm{H}$ pada daerah 3200-3600 $\mathrm{cm}^{-1}$, sedangkan lateks tidak. Gugus C-O alkohol juga terdeteksi pada daerah 1091,83 $\mathrm{cm}^{-1}$ untuk lateks terhidrasi $10 \%$ katalis, serta $1059,28 \mathrm{~cm}^{-1}$ untuk lateks terhidrasi $20 \%$ dan $30 \%$ katalis. Hal ini mengindikasikan bahwa lateks telah berhasil dihidrasi. Gugus $\mathrm{C}=\mathrm{C}$ masih terdeteksi pada ketiga variasi hidrasi di daerah 1643,86 $\mathrm{cm}^{-1}$, $1635,64 \mathrm{~cm}^{-1}$ dan $1651,07 \mathrm{~cm}^{-1}$, hal ini menunjukkan bahwa tidak semua ikatan rangkap pada lateks berhasil dihidrasi. Namun demikian berdasarkan analisis gugus fungsi ditunjukkan bahwa penambahan katalis $30 \%$ terjadi pergeseran bilangan gelombang untuk serapan $\mathrm{O}-\mathrm{H}$ pada bilangan gelombang yang paling rendah yaitu $3417,85 \mathrm{~cm}^{-1}$ dan dengan puncak serapan O-H lebih melebar, hal ini menunjukkan bahwa penggunaan 30\% katalis menghasilkan lateks terhidrasi dengan kandungan gugus $\mathrm{O}-\mathrm{H}$ bebas lebih banyak dibandingkan yang lainnya. Dengan demikian penggunaan katalis sebanyak 30\% merupakan konsentrasi optimum untuk menghidrasi lateks.

\section{Analisis Viskositas}

Karakterisasi selanjutnya adalah viskositas lateks terhidrasi untuk mengetahui pengaruh hidrasi terhadap viskositas lateks. Pengukuran viskositas menggunakan viskometer Ostwald dilakukan dengan membandingkan waktu alir larutan sampel pada konsentrasi $(\mathrm{m} / \mathrm{m}) 0,1 \%, 0,25 \%$, $0,5 \%, 0,75 \%$ dan $1 \%$ dengan pelarutnya. Viskosi- tas intrinsik diperoleh dengan mengekstrapolasikan viskositas reduksi ke konsentrasi nol.

Tabel 2 memberikan informasi bahwa terjadi penurunan viskositas pada lateks setelah dilakukan hidrasi. Proses hidrasi pada lateks ini dilakukan pada suhu $50^{\circ} \mathrm{C}$ selama 1 jam sehingga penurunan viskositas pada lateks setelah hidrasi karena pengaruh panas maka polimer dapat mengalami perombakan menjadi monomer-monomernya atau terjadi reaksi kebalikan dari polimerisasi (depolimerisasi).

Dengan suhu dan waktu pemanasan yang sama, pada variasi hidrasi lateks dengan $20 \%$ katalis terlihat bahwa viskositasnya meningkat dibandingkan dengan penambahan $10 \%$ katalis dari $12,93 \mathrm{~mL} / \mathrm{g}$ menjadi $23,74 \mathrm{~mL} / \mathrm{g}$. Hal ini dimungkinkan karena ikatan rangkap pada variasi kedua ini lebih banyak terhidrasi membentuk ikatan $-\mathrm{OH}$ sehingga meningkatkan massa molekulnya. Bertambahnya massa molekul akan mengurangi kelarutan suatu polimer, hal ini berarti viskositasnya akan meningkat. Penambahan 30\% katalis justru terjadi penurunan viskositas menjadi $22,67 \mathrm{~mL} / \mathrm{g}$ dibandingkan dengan penambahan $20 \%$ katalis akan tetapi lebih tinggi dari penambahan $10 \%$ katalis. Penurunan viskositas ini kemungkinan disebabkan oleh kelebihan asam yang mengakibatkan gugus $-\mathrm{OH}$ yang telah terbentuk justru terprotonasi dan terlepas kembali sebagai molekul air.

\section{Modifikasi Matriks dan Karakterisasinya}

Matriks alam sekresi kutu lak ini selanjutnya dimodifikasi dengan menambahkan lateks terhidrasi. Pada pencampuran antara sekresi kutu lak dengan lateks terhidrasi, terjadi reaksi antara gugus $-\mathrm{COOH}$ pada asam aleurat yang merupakan penyusun utama sekresi kutu lak dengan gugus - $\mathrm{OH}$ pada lateks terhidrasi membentuk suatu ester.

Apabila asam karboksilat dan alkohol dipanaskan dengan katalis asam (biasanya $\mathrm{HCl}$ atau $\mathrm{H}_{2} \mathrm{SO}_{4}$ ), terbentuk kesetimbangan ester dan air.

Tabel 2. Data viskositas intrinsik lateks dan lateks terhidrasi.

\begin{tabular}{lc}
\hline \multicolumn{1}{c}{ Sampel } & Viskositas intrinsik $(\mathrm{mL} / \mathrm{g})$ \\
\hline Lateks & 422,30 \\
Lateks terhidrasi dengan 10\% katalis & 12,93 \\
Lateks terhidrasi dengan 20\% katalis & 23,74 \\
Lateks terhidrasi dengan 30\% katalis & 22,67 \\
\hline
\end{tabular}


Katalis yang digunakan pada modifikasi ini adalah $\mathrm{H}_{2} \mathrm{SO}_{4}$ pekat. Hal ini disebabkan karena kecepatan pembentukan ester sangat kecil, tetapi dapat diperbesar oleh daya katalis asam klorida yang tidak mengandung air atau asam sulfat yang pekat. Lateks terhidrasi dengan katalis 30\% dicampurkan dengan sekresi kutu lak pada variasi konsentrasi $5 \%, 10 \%$ dan $15 \%(\mathrm{~m} / \mathrm{m})$. Proses pencampuran antara sekresi kutu lak dengan lateks terhidrasi dilakukan menggunakan magnetic stirer dengan suhu $60^{\circ} \mathrm{C}$ selama $1 \mathrm{jam}$. Matriks yang dihasilkan berbentuk gel dan berwarna coklat kemerahan.

Modifikasi matriks menggunakan lateks terhidrasi memungkinkan terjadinya reaksi esterifikasi antara gugus $-\mathrm{OH}$ pada lateks terhidrasi dengan gugus $-\mathrm{COOH}$ pada asam aleurat. Gambar 6 menunjukkan mekanisme reaksi esterifikasi yang terjadi.

Tahap pertama pada reaksi ini adalah katalisis asam. Gugus karbonil pada asam aleurat diprotonasi. Proses ini meningkatkan muatan positif pada karbon karboksil dan menjadikannya sasaran yang baik bagi nukleofil. Tahap kedua, alkohol pada lateks terhidrasi sebagai nukleofil menyerang kar- bon karbonil dari asam aleurat yang telah terprotonasi. Pada tahap ini terbentuk ikatan ester (C-O). Tahap ketiga adalah tahap kesetimbangan dimana oksigen melepaskan dan mendapatkan proton. Tahap keempat, salah satu gugus hidroksil terprotonasi yang meningkatkan kapasitas gugus $-\mathrm{OH}$ untuk terlepas pada tahap selanjutnya. Pada tahap ini tidak jadi masalah mana gugus - $\mathrm{OH}$ yang terprotonasi, karena kedua gugus tersebut identik. Tahap yang kelima terjadi pemutusan $\mathrm{C}-\mathrm{O}$ dan lepasnya air. Tahap yang keenam, ester yang berproton melepaskan protonnya.

Tabel 3 menunjukkan serapan pada spektrum FTIR matriks dengan penambahan lateks sebanyak $5 \%, 10 \%$ dan $15 \%$. Ketiga matriks dengan penambahan lateks tanpa hidrasi memiliki kesamaan gugus fungsi, ketiga variasi tersebut menunjukkan adanya serapan $\mathrm{C}=\mathrm{O}$ dari gugus karboksilat pada daerah $1712,7 \mathrm{~cm}^{-1}, 1712,79 \mathrm{~cm}^{-1}$, dan $1710,86 \mathrm{~cm}^{-1}$, terdapat juga serapan gugus $\mathrm{O}-\mathrm{H}$ pada daerah $3441,02 \mathrm{~cm}^{-1}, 3371,57 \mathrm{~cm}^{-1}, 3410,15$ $\mathrm{cm}^{-1}, 3429,43 \mathrm{~cm}^{-1}$ dan serapan C-O alkohol pada daerah $1111 \mathrm{~cm}^{-1}, 1145,72 \mathrm{~cm}^{-1}, 1118,71 \mathrm{~cm}^{-1}$, $1083,99 \mathrm{~cm}^{-1}$. Data ini bersesuaian dengan pe-

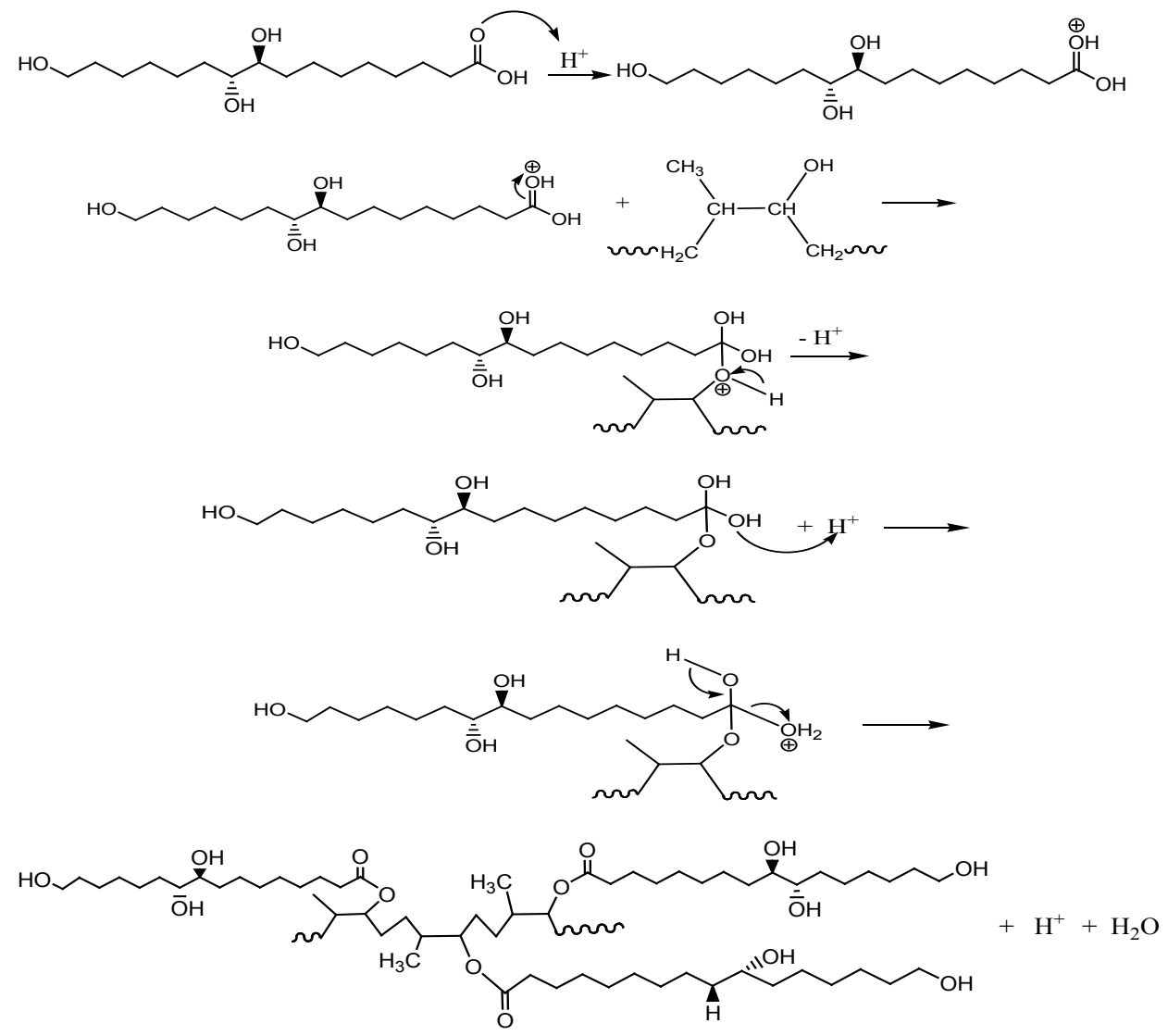

Gambar 6. Mekanisme reaksi esterifikasi lateks terhidrasi dengan asam aleurat. 
nyusun utama sekresi kutu lak yaitu asam aleurat, memiliki 16 rantai karbon dengan gugus karboksilat dan 3 hidroksil (Gambar 6).

Yalong et al. (2015) mengungkapkan bahwa shellac tersusun dari berbagai macam hidroksi alifatik dan esternya, hal ini mendukung adanya gugus ester pada sekresi kutu lak (SKL) yang digunakan sebagai bahan dasar matriks. Selain itu, Kumpugdee-Vollrath et al. (2014) dan Patel et al. (2013) memberikan informasi yang mendukung keberadaan gugus ester pada SKL dimana shellac memberikan intepretasi gugus fungsi pada daerah $1735 \mathrm{~cm}^{-1}$ dari ester dan $1715 \mathrm{~cm}^{-1}$ dari asam. Apabila dilihat dari struktur lateks yang merupakan sebuah alkena dengan gugus utama karbon berikatan rangkap dua, kemungkinan ester yang terdeteksi bukan ester yang terbentuk dari lateks dengan asam aleurat tetapi ester dalam sekresi kutu lak seperti yang telah dijelaskan.

Spektrum FTIR matriks alam sekresi kutu lak tanpa modifikasi lateks terhidrasi digunakan sebagai pembanding untuk mengetahui terbentuknya gugus ester antara lateks terhidrasi dengan asam aleurat pada sekresi kutu lak. Spektrum FTIR matriks termodifikasi dengan 5\%,10\% dan $15 \%$ lateks terhidrasi terlihat memiliki serapan gugus fungsi yang sama. Identifikasi selengkapnya ditampilkan pada Tabel 4.

Seperti yang telah diketahui bahwa reaksi asam karboksilat dengan alkohol menggunakan katalis asam akan menghasilkan senyawa ester melalui reaksi yang dikenal dengan nama esterifikasi (Riswiyanto, 2009), maka penambahan lateks yang telah dihidrasi ke dalam asam aleurat akan menghasilkan senyawa ester. Tabel 4 menunjukkan bahwa pada ketiga variasi modifikasi terdapat gugus ester dimana $\mathrm{C}=\mathrm{O}$ ester muncul di daerah $1737,85 \mathrm{~cm}^{-1}, 1737,86 \mathrm{~cm}^{-1}$, dan 1737,86 $\mathrm{cm}^{-1}$, diperkuat dengan munculnya serapan $\mathrm{C}-\mathrm{O}$ ester pada daerah $1211,3 \mathrm{~cm}^{-1}, 1251,8 \mathrm{~cm}^{-1}$, dan $1286,52 \mathrm{~cm}^{-1}$ pada variasi pertama, $1251,8 \mathrm{~cm}^{-1}$ dan $1284,59 \mathrm{~cm}^{-1}$ pada variasi kedua, serta 1251,8 $\mathrm{cm}^{-1}$ dan $1286,52 \mathrm{~cm}^{-1}$ pada variasi ketiga.

Apabila dibandingkan antara matriks termodifikasi dengan matriks tanpa modifikasi, keduanya menunjukkan adanya gugus ester. Terdapat 2 kemungkinan keberadaan ester pada matriks yang telah termodifikasi lateks hidrasi ini. Kemungkinan pertama, ester yang terdeteksi merupakan komponen dari SKL seperti yang juga terdapat pada matriks tanpa modifikasi. Kemungkinan yang kedua adalah terbentuknya ester antara $-\mathrm{OH}$

Tabel 3. Serapan FTIR matriks dengan penambahan lateks tanpa hidrasi.

\begin{tabular}{|c|c|c|c|c|}
\hline Ikatan atom & $\begin{array}{l}\text { Rentang gelombang } \\
\left(\mathrm{cm}^{-1}\right)\end{array}$ & $\begin{array}{c}\text { Matriks 5\% lateks } \\
\left(\mathrm{cm}^{-1}\right)\end{array}$ & $\begin{array}{c}\text { Matriks } 10 \% \text { lateks } \\
\left(\mathrm{cm}^{-1}\right)\end{array}$ & $\begin{array}{l}\text { Matriks } 15 \% \\
\text { lateks }\left(\mathrm{cm}^{-1}\right)\end{array}$ \\
\hline \multirow[t]{2}{*}{$\mathrm{C}=\mathrm{O}$} & $\begin{array}{l}1700-1725 \\
\text { (Karbonil) }\end{array}$ & 1712,7 & 1712,79 & 1710,86 \\
\hline & $\begin{array}{l}\text { 1730-1750 } \\
\text { (Ester) }\end{array}$ & 1730,15 & 1733,33 & 1734,51 \\
\hline \multicolumn{5}{|l|}{$\mathrm{C}-\mathrm{O}$} \\
\hline Ester & $1180-1300$ & 1188,15 & 1249,87 & 1244,09 \\
\hline Alkohol & $1050-1150$ & $\begin{array}{c}1111 ; \\
1145,72\end{array}$ & 1118,71 & 1083,99 \\
\hline $\mathrm{O}-\mathrm{H}$ & $3200-3600$ & 3441,01 & $\begin{array}{l}3371,57 \\
3410,15\end{array}$ & 3429,43 \\
\hline $\mathrm{C}=\mathrm{C}$ & $1620-1680$ & $\begin{array}{l}1631,78 ; 1643,35 \\
1649,14 ; 1670,35\end{array}$ & 1635,64 & $\begin{array}{l}1620,21 \\
1664,57\end{array}$ \\
\hline \multicolumn{5}{|l|}{$\mathrm{C}-\mathrm{H}$} \\
\hline Stretching & $2800-3100$ & 2833,$73 ; 2858,73$ & $\begin{array}{c}2924,09 \\
2862,36\end{array}$ & $\begin{array}{l}2962,66 \\
2929,87 \\
2854,65\end{array}$ \\
\hline Bending & $1300-1480$ & 1469,76 & $\begin{array}{c}1373,32 \\
1458,18\end{array}$ & $\begin{array}{c}1307,74 \\
1375,25 \\
1450,47\end{array}$ \\
\hline
\end{tabular}


pada lateks yang telah terhidrasi dengan $-\mathrm{COOH}$ pada asam aleurat. Apabila dilihat dari serapannya, serapan $\mathrm{C}=\mathrm{O}$ matriks termodifikasi lateks hidrasi menyerap beberapa $\mathrm{cm}^{-1}$ lebih jauh dari matriks tanpa modifikasi yaitu pada daerah $1737,85 \mathrm{~cm}^{-1}$, $1737,86 \mathrm{~cm}^{-1}$ dan $1737,86 \mathrm{~cm}^{-1}$ sedangkan serapan $\mathrm{C}=\mathrm{O}$ matriks tanpa modifikasi terdeteksi di daerah $1730,15 \mathrm{~cm}^{-1}, 1733,33 \mathrm{~cm}^{-1}$, dan $1734,52 \mathrm{~cm}^{-1}$. Hal ini memberikan kemungkinan adanya perbedaan ikatan ester pada matriks sebelum dan sesudah modifikasi, sehingga dapat disimpulkan bahwa ketiga variasi matriks termodifikasi telah berhasil diesterifikasi.

Terbentuknya ikatan ester antara lateks terhidrasi dengan SKL pada matriks termodifikasi akan memberikan bobot molekul yang lebih be- sar dibandingkan dengan matriks tanpa modifikasi dimana lateks yang ditambahkan tidak berikatan dengan SKL. Viskositas intrinsik pada matriks dianalisis untuk mengetahui pengaruh modifikasi matriks terhadap viskositasnya. Tabel 5 menunjukkan viskositas intrinsik matriks tanpa modifikasi. Viskositas intrinsik matriks juga dibandingkan dengan viskositas intrinsik matriks termodifikasi lateks hidrasi agar diketahui perbedaan viskositas matriks sebelum dan setelah modifikasi. Tabel 6 menunjukkan viskositas intrinsik matriks termodifikasi lateks hidrasi.

Tabel 5 dan 6 menunjukkan adanya peningkatan viskositas matriks tanpa modifikasi dan matriks termodifikasi dengan penambahan lateks hasil hidrasi. Peningkatan viskositas disebabkan

Tabel 4. Serapan IR matriks termodifikasi oleh lateks hasil hidrasi dengan katalis 30\%.

\begin{tabular}{|c|c|c|c|c|}
\hline Ikatan atom & $\begin{array}{l}\text { Rentang gelombang } \\
\left(\mathrm{cm}^{-1}\right)\end{array}$ & $\begin{array}{c}\text { Matriks 5\% lateks } \\
\text { hidrasi }\left(\mathrm{cm}^{-1}\right)\end{array}$ & $\begin{array}{c}\text { Matriks } 10 \% \text { lateks } \\
\text { hidrasi }\left(\mathrm{cm}^{-1}\right)\end{array}$ & $\begin{array}{c}\text { Matriks } 15 \% \text { lateks } \\
\text { hidrasi }\left(\mathrm{cm}^{-1}\right)\end{array}$ \\
\hline \multirow[t]{2}{*}{$\mathrm{C}=\mathrm{O}$} & $\begin{array}{l}1700-1725 \\
\text { (Karbonil) }\end{array}$ & 1714,$72 ; 1722,43$ & 1714,$72 ; 1722,43$ & 1714,$72 ; 1722,43$ \\
\hline & $\begin{array}{l}1730-1750 \\
\text { (Ester) }\end{array}$ & 1737,85 & 1737,86 & 1737,86 \\
\hline \multicolumn{5}{|l|}{$\mathrm{C}-\mathrm{O}$} \\
\hline Ester & $1180-1300$ & $\begin{array}{c}1211,3 ; 1251,8 ; \\
1286,52\end{array}$ & 1251,$8 ; 1284,59$ & 1251,$8 ; 1286,52$ \\
\hline Alkohol & $1050-1150$ & 1068,56 & 1070,49 & 1070,49 \\
\hline $\mathrm{O}-\mathrm{H}$ & $3200-3600$ & 3444,87 & $\begin{array}{c}3417,86 ; 3444,87 \\
3477,66 ; 3562,52 \\
3583,74\end{array}$ & 3439,$08 ; 3506,59$ \\
\hline $\mathrm{C}=\mathrm{C}$ & $1620-1680$ & $\begin{array}{c}1633,71 ; 1643,35 \\
1651,07\end{array}$ & $\begin{array}{c}1633,71 ; 1645,28 \\
1651,07 ; 1660,71 \\
1668,43\end{array}$ & 1651,07; 1668,43; \\
\hline \multicolumn{5}{|l|}{$\mathrm{C}-\mathrm{H}$} \\
\hline Stretching & $2800-3100$ & 2860,$43 ; 2931,8$ & 2862,$36 ; 2931,8$ & $\begin{array}{c}2864,29 ; 2931,8 ; \\
2954,95\end{array}$ \\
\hline Bending & $1300-1480$ & $\begin{array}{c}1361,74 ; 1367,53 \\
1377,17\end{array}$ & $\begin{array}{c}1361,74 ; 1367,53 \\
1371,39 ; 1454,33 \\
1469,76 \\
\end{array}$ & $\begin{array}{c}1361,74 ; 1371,39 ; \\
1379,1 ; 1454,33 \\
1462,04\end{array}$ \\
\hline
\end{tabular}

Tabel 5. Data viskositas intrinsik matriks dan matriks dengan penambahan lateks tanpa hidrasi

\begin{tabular}{lc}
\hline \multicolumn{1}{c}{ Sampel } & Viskositas intrinsik $(\mathrm{mL} / \mathrm{g})$ \\
\hline Matriks & 42,536 \\
Matriks dengan 5\% lateks tanpa hidrasi & 45,621 \\
Matriks dengan 10\% lateks tanpa hidrasi & 51,369 \\
Matriks dengan 15\% lateks tanpa hidrasi & 57,015 \\
\hline
\end{tabular}


adanya ikatan yang terjadi antara matriks alam sekresi kutu lak dengan lateks terhidrasi sehingga viskositas matriks bertambah dan berpengaruh terhadap massa molekulnya. Matriks termodifikasi dengan penambahan $10 \%$ lateks terhidrasi lebih besar dibandingkan dengan matriks termodifikasi $5 \%$ lateks terhidrasi, akan tetapi pada modifikasi dengan penambahan $15 \%$ lateks terhidrasi mengalami penurunan dari $67,19 \mathrm{~mL} / \mathrm{g}$ menjadi 52,23 $\mathrm{mL} / \mathrm{g}$. Penurunan viskositas pada matriks variasi ketiga ini dimungkinkan karena lateks tidak bisa bercampur homogen dengan matriks. Massa molekul yang terlalu tinggi bisa menyebabkan kesukaran-kesukaran dalam pemrosesannya dan paduan-paduan polimer yang homogen lebih baik dari segi sifat atau karakteristik pemrosesannya.

Viskositas matriks termodifikasi lateks 10\% terhidrasi memiliki viskositas terbesar di antara variasi yang lain, oleh karena itu matriks yang digunakan sebagai matriks penyusun biokomposit adalah matriks dengan penambahan lateks terhidrasi sebanyak $10 \%$.

\section{Biokomposit dan Karakterisasinya}

Biokomposit dibuat dengan mencampurkan matriks alam sekresi kutu lak termodifikasi dan serat rami dengan perbandingan $60 \%$ serat dan $40 \%$ matriks. Cetakan yang digunakan berukuran $180 \mathrm{~mm} \times 180 \mathrm{~mm} \times 8 \mathrm{~mm}$, sehingga dapat diketahui berat matriks yang diperlukan adalah sebanyak 259,718 gram dan serat rami yang dibutuhkan sebanyak 165,88 gram. Serat rami yang digunakan berukuran panjang $10 \mathrm{~cm}$ dan disusun secara acak. Serat rami yang akan digunakan (165,88 gram) terlebih dahulu dipres pada cetakan agar pada saat pencetakan biokomposit, serat rami tersusun rapi. Selanjutnya matriks (259,718 gram) dipanaskan terlebih dahulu untuk menghilangkan pelarut yang terdapat di dalamnya. Setelah pelarut dalam matriks sudah menguap, serat rami yang telah dipres kemudian dicampurkan. Campuran antara matriks dengan serat rami kemudian dipres dengan tekanan $150 \mathrm{MPa}$ pada suhu $150^{\circ} \mathrm{C}$ selama 15 menit dan didiamkan selama 3 jam sampai suhu kamar. Biokomposit yang telah dicetak diuji sifat mekaniknya menggunakan tensile tester. Lembaran biokomposit terlebih dahulu dipotong dalam bentuk dumbble sesuai standar ASTM D 638-90. Análisis sifat mekanik yang dilakukan berupa kuat putus $(\sigma)$, elongasi $(\varepsilon)$, dan modulus Young (E). Data hasil uji kekuatan mekanik biokomposit termodifikasi lateks hidrasi ditunjukkan pada Tabel 7 .

Biokomposit tanpa modifikasi didapatkan kuat tarik sebesar 0,932 MPa (932.000 Pa) sedangkan biokomposit termodifikasi memiliki kuat tarik sebesar 0,982 $\mathrm{MPa}(982.500 \mathrm{~Pa})$. Hasil ini menunjukkan adanya peningkatan kuat tarik pada biokomposit dengan matriks alam yang telah dimodifikasi menggunakan lateks terhidrasi dibandingkan dengan penambahan lateks tanpa hidrasi. Apabila dibandingkan dengan hasil penelitian Mujiyono et al. (2010) dan Puspita (2013), kuat tarik dari biokomposit yang diperoleh dalam penelitian ini lebih kecil. Hal ini dapat disebabkan oleh susunan serat rami yang digunakan saat pembuatan biokomposit berbeda. Susunan serat acak dan yang dianyam akan menghasilkan kuat tarik biokomposit yang berbeda.

Berbeda dengan kuat tarik, elongasi pada biokomposit termodifikasi jauh lebih kecil dibandingkan dengan biokomposit pembandingnya.

Tabel 6. Data viskositas intrinsik matriks dan matriks dengan penambahan lateks hidrasi.

\begin{tabular}{lc}
\hline \multicolumn{1}{c}{ Sampel } & Viskositas intrinsik $(\mathrm{mL} / \mathrm{g})$ \\
\hline Matriks dengan 5\% lateks terhidrasi & 60,79 \\
Matriks dengan 10\% lateks terhidrasi & 67,19 \\
Matriks dengan 15\% lateks terhidrasi & 52,23 \\
\hline
\end{tabular}

Tabel 7. Sifat mekanik biokomposit dari matriks alam sekresi kutu lak termodifikasi lateks tanpa dan dengan hidrasi dengan penguat serat rami.

\begin{tabular}{cccc}
\hline Sampel & Kuat tarik (MPa) & Elongasi (\%) & Modulus Young \\
\hline Lateks tanpa hidrasi & 0,932 & 2,074 & 0,457 \\
Lateks terhidrasi 10\% & 0,982 & 1,189 & 0,929 \\
\hline
\end{tabular}


Pada biokomposit termodifikasi menunjukkan elongasi sebesar $1,189 \%$, sedangkan biokomposit tanpa modifikasi menunjukkan elongasi sebesar 2,074\%. Tang \& Takashu (2015) mengungkapkan adanya ikatan rangkap pada rantai polimer cenderung mendorong terbentuknya ikatan sambung silang (cross links) yang menyebabkan polimer berubah menjadi keras/getas. Seperti yang telah diketahui bahwa tidak sepenuhnya ikatan rangkap dua pada lateks telah terhidrasi, maka ada kemungkinan terjadi ikatan sambung silang pada matriks termodifikasi ini sehingga nilai elongasinya menjadi lebih kecil. Matriks tanpa modifikasi lateks hidrasi juga memiliki kemungkinan untuk berikatan sambung silang, akan tetapi pada matriks termodifikasi terjadi ikatan antara lateks terhidrasi dengan SKL sedangkan pada matriks tanpa modifikasi tidak. Hal ini memberikan ikatan yang lebih kompleks pada matriks termodifikasi lateks hidrasi sehingga memiliki nilai elongasi yang lebih kecil. Rahman \& Kamiel (2011) menjelaskan bahwa besarnya elongasi menunjukkan kemampuan benda mengubah bentuk. Nilai elongasi kecil disebabkan kuatnya ikatan antara matriks dengan serat penguat. Semakin kuat ikatannya, regangan yang terjadi semakin kecil. Hal ini menunjukkan bahwa ikatan antara matriks termodifikasi lateks hidrasi dengan serat rami lebih kuat dibandingkan dengan matriks tanpa modifikasi lateks.

Berdasarkan data yang diperoleh, biokomposit tanpa modifikasi memiliki Modulus Young sebesar 0,457 MPa sedangkan biokomposit termodifikasi memiliki Modulus Young sebesar 0,929 MPa. Semakin besar Modulus Young maka semakin kaku bahan komposit tersebut (Arash et al., 2014).

\section{KESIMPULAN}

Matriks dari sekresi kutu lak berhasil dimodifikasi dengan penambahan lateks terhidrasi. Proses hidrasi terhadap lateks berhasil dilakukan pada semua variasi katalis $(10 \%, 20 \%$ dan $30 \%)$, dengan konsentrasi katalis optimum pada variasi $30 \%$ katalis. Variasi jumlah katalis mempengaruhi viskositas intrinsik lateks terhidrasi. Penambahan lateks hasil hidrasi ke dalam matriks alam sekresi kutu lak berpengaruh terhadap viskositas dan gugus fungsi matriks ditandai dengan munculnya gugus ester pada semua variasi penambahan lateks hasil hidrasi $(5 \%, 10 \%$ dan $15 \%)$, dengan matriks termodifikasi optimum pada variasi penambahan lateks terhidrasi sebanyak 10\%. Penggunaan ma- triks termodifikasi dengan lateks terhidrasi dapat meningkatkan kuat tarik dan kekakuan biokomposit. Biokomposit termodifikasi lateks terhidrasi memiliki kuat tarik sebesar 0,982 $\mathrm{MPa}$, elongasi 1,189\% dan Modulus Young 0,929 MPa.

\section{UCAPAN TERIMA KASIH}

Ucapan terima kasih disampaikan kepada Ditlitabmas Dikti Kementerian Pendidikan dan Kebudayaan RI yang telah memberikan kesempatan untuk melakukan penelitian Strategi Nasional sesuai dengan Surat Perjanjian Pelaksanaan Penugasan Penelitian Strategi Nasional nomor 124/ SP2H/PL/DIT.LITABMAS/V/2013 tanggal 13 Mei 2013.

\section{DAFTAR PUSTAKA}

Adistya, R. (2013). Sifat mekanik biokomposit serat rami (Boehmeria Nivea L.) dengan matriks propilen (Skripsi). Institut Pertanian Bogor, Indonesia.

Agustin, M. B., Ahmmad, B., De Leon, E. R. P., Buenaobra, J. L., Salazar, J. R., \& Hirose, F. (2014). Starch-based biocomposite films reinforced with cellulose nanocrystals from garlic stalks. Polymer Composites, 34(8), 1325-1332.

Ahmed, N. M., Tawfik, M. E., \& Ward, A. A. (2013). Characterization of a polymer composite from treated kaolin and unsaturated polyester based on PET waste. Polymer Composites, 34(8), 12231234.

Arash, B., Wang, Q., \& Varadan, V. K. ((2014). Mechanical properties of carbon nanotube/polymer composites. Scientific Report, 4(1), 2045-2322

Feng, Y., Hu, Y., Zhao, G., Yin, J., \& Jiang, W. (2011). Preparation and mechanical properties of highperformance short ramie fiber-reinforced polypropylene composites. Jornal of Applied Polymer Science, 122(3),1564-1571.

Kumpugdee-Vollrath, M., Tabatabaeifar, M., \& Helmis, M. (2014). New coating materials based on mixtures of shellac and pectin for pharmaceutical products. International Journal of Medical, Health, Biomedical and Pharmaceutical Engineering, 8(1), 21-29.

Lokana, I. P., Suardana, N. G. P., \& Karonika, I. M. G. N. (2010). Pengaruh panjang serat pada temperatur uji yang berbeda terhadap kekuatan tarik komposit polyester serat tapis kelapa. Jurnal Ilmiah Teknik Mesin, 4(2),166-172.

Mujiyono, Jamasri, Heru S. B. R, \& Gentur, S. J. P. (2010). Rekayasa biokomposit dari sekresi kutu lak dan serat rami. Dalam Seminar Nasional Hasil-hasil Penelitian Teknologi, MIPA dan Pendidikan Vokasi. Yogyakarta, Indonesia. 
Oroh, J., Sappu, F. P., \& Lumintang, R. (2013). Analisis sifat mekanik komposit dari serat sabut kelapa. Artikel Ilmiah. Manado, Indonesia: Universitas Sam Ratulangi.

Patel, A. R., Schatteman, D., Vos, W. H. D., Lesaffer, A., \& Dewettinck, K. (2013). Preparation and rheological characterization of shellac oleogels and oleogel-based emulsions. Journal of Colloid Interface Science, 411, 114-121.

Purwati, R. D. (2010). Strategi pengembangan rami (Boehmeria nivea Gaud.). Jurnal Perspektiv, 9(2), 106-108.

Puspita, R. (2013). Modifikasi sekresi kutu lak dengan lateks sebagai matriks alam dalam preparasi biokomposit berpenguat serat rami (Skripsi). Universitas Negeri Yogyakarta, Indonesia.

Quirino, R. L., Garrison, T. F., \& Kessler, M. R. (2014) Matrices from vegetable oils, cashews nut shell liquid, and other relevant systems for biocomposite applications. Green Chemistry, 16(1), 17001715.

Rahman, M. B. N. \& Kamiel, B. P. (2011). Pengaruh fraksi volume serat terhadap sifat-sifat tarik komposit diperkuat undirectional serat tebu dengan matriks poliester. Jurnal Ilmiah Semesta Teknika, 14(2), 133-138.

Riswiyanto. (2009). Kimia organik. Jakarta, Indonesia: Erlangga.
Rudianto, R. (2012). Pengaruh fraksi volume serat rami terhadap kekuatan bending biokomposit bermatriks pati sagu. Jurnal Teknik Mesin, 1(1), 8-12.

Sordi, D., De Ruijter, C., Orlanducci, S., Picken, S. J., Sudholter, E. J. R., Terranova, M. L., de Smet, L. C. P. M., \& Dingemans, T. J. (2011). Sulfonated liquid crystalline polyesters as resin matrix for single wall carbon nanotube and nanodiamond composites. Journal of Polymer Science, 49(5), 1079-1087.

Tang, T. \& Takasu, A. (2015). Facile synthesis of unsaturated polyester-based double-network gels via chemoselective cross-linking using michael addition and subsequent UV-initiated radical polymerization. RSC Advanced, 5(1), 819-829.

Taskirawati, I., Suratmo, F. G., Darusman, D., \& Haneda, N. F. (2008). Peluang investasi usaha budidaya kutu lak (Laccifer lacca Kerr): Studi kasus di KPH Probolinggo Perum Perhutani Unit II Jawa Timur. Jurnal Perennial, 4(1),23-27.

Yalong, L., Juan, Z., Feirong, H., \& Bingjie, L. (2015). Effects of combined chlorine on physicochemical properties and structure of shellac. Journal of Pharmaceutical Sciences, 28(1), 329-334. 
